\title{
FERMENTED BEVERAGE BASED ON WATER-SOLUBLE SOYBEAN EXTRACT
}

\author{
BEBIDA FERMENTADA À BASE DE EXTRATO HIDROSOLÚVEL DE SOJA
}

\section{Thaysa Bazana BESSEGATO ${ }^{1}$; José Renato SILVA²; Kaio Maciel de Santiago SILVA ${ }^{2}$; Emely Osti ZANON ${ }^{2}$; Jaqueline CAMISA ${ }^{2,3}$; Giselle Nobre $\operatorname{COSTA}^{3 *}$}

1. Chemistry Bachelor Degree, University Pitágoras Unopar, Arapongas, Parana, Brazil. 2. Master's degree in the Program Science and Technology of Milk and Dairy Products, University Pitágoras Unopar, Londrina, Parana, Brazil; 3. Ph.D. Professor, Program Science and Technology of Milk and Dairy Products University Pitágoras Unopar, Londrina, Parana, Brazil. *giselle.nobre@unopar.br, gcnobre@gmail.com

\begin{abstract}
Functional foods are those that, beyond basic nutrition, promote health benefits. This study aimed to produce a fermented beverage from a water-soluble soybean extract and low-lactose semiskimmed milk. The beverage was prepared using a blend (v/v) containing $62 \%$ water-soluble soybean extract, $33 \%$ low-lactose semi-skimmed milk, and 5\% of an inoculum containing Lactobacillus delbrueckii subsp. bulgaricus and Streptococcus salivarius subsp. thermophilus. The fermentation was carried out with monitoring of the lactic acid bacteria (LAB) counts, $\mathrm{pH}$, and titrable acidity (\% lactic acid). The consumption-ready fermented beverage was added of strawberry syrup and posteriorly characterized by its centesimal composition and sensory attributes as appearance, aroma, flavour, texture, overall impression, and purchase intent. Additionally, the LAB count and presence of pathogens in the final product were evaluated. After $14 \mathrm{~h}$ of fermentation, the refrigerated product presented L. bulgaricus and S. thermophilus counts of $8.5 \times 10^{3}$ and $7.4 \times$ $10^{7} \mathrm{CFU} / \mathrm{mL}$, respectively. The product contained $14.93 \%$ carbohydrates, $0.76 \%$ fats, $0.96 \%$ ash, $22.76 \%$ total solids, and $2.19 \%$ protein. Because the product did not present any pathogens, it was adequate according to the standards of microbiological safety determined by Brazilian legislation. Regarding the sensory evaluation, the panelists assigned a mean score of 7.0 for the attributes evaluated, indicating 'liked moderately' to the drink. In addition, $61 \%$ of the evaluators responded that they 'certainly or probably would buy' the product if it were available on the market.
\end{abstract}

KEYWORDS: Streptococcus thermophiles. Lactobacillus bulgaricus. Soybeans. Low-lactose product.

\section{INTRODUCTION}

Functional foods are defined as any food or food ingredient that may provide health benefits beyond basic nutrition, and promote physiological benefits to the consumer (BRAZIL, 2016; MARTIROSYAN and SINGH, 2015; WALKER et al., 2006). This includes foods that have been modified to become functional, or which naturally contain bioactive compounds (MARTIROSYAN; SINGH, 2015; SHAH, 2007).

The soybean (Glycine max) and its derivatives have received attention from researchers for the quantity and quality of its protein, which is considered the best substitute for animal protein among vegetables (ANGELIS, 2012; BREN, SANTOS, ALMEIDA, 2010; PENHA et al., 2007). Furthermore, it is an important source of fibre, vitamins, minerals, isoflavones, and oligosaccharides, with prebiotic potential (FUCHS et al., 2005).

The US Food and Drug Administration and the Brazilian National Sanitary Surveillance Agency
(ANVISA) both allow a health claim for soy protein (BRAZIL, 2016; UNITED STATES, 1999). Additionally, studies have linked the intake of soy products to improvements in menopausal symptoms; the prevention of osteoporosis and cancer, especially breast and prostate cancers; the lowering of blood pressure, cholesterol, and triglycerides; and slowing of the progression of chronic renal failure and Alzheimer's disease; as well as to their activities in vascular reactivity and as an angiogenesis inhibitor (KEMPKA et al., 2008).

Despite its high productivity and nutritional and functional properties, the soybean is hardly used in the Brazilian diet owing to the presence of lipoxygenase enzymes that act on the polyunsaturated fatty acids, producing an unpleasant flavour and odour (MARTINS et al., 2002). Additionally, the oligosaccharides and antinutritional components of the soybean can cause flatulence. Because of these factors, most of the soybeans produced in the country are used in oil extraction and animal feed (SILVA et al., 2006). 
However, scientific studies have sought viable alternatives aimed at increasing the possibilities of introducing soybeans into human food (HUAG, CAI, XU, 2017; VAGADIA, et al., 2018; WATANABE, et al., 2016).

The water-soluble extract of the soybean, which is rich in protein and has a low level of fatty acids, has been commercialized in the forms of granules, powder, and liquid. The extract does not contain lactose, thus allowing its consumption by lactase-deficient individuals. However, it is a suitable medium for the growth of lactic acid bacteria (LAB) because it contains substances that favour the metabolism of these microorganisms, such as raffinose, stachyose, amino acids, and proteins (OMOGBAI, IKENEBOMEH, OJEABURU, 2005).

Yogurt is the product of milk fermentation by Lactobacillus delbrueckii subsp. bulgaricus and Streptococcus salivarius subsp. thermophilus (BRAZIL, 2000; BRAZIL, 2007), and has a high nutritional value and high digestibility (CAMARGO et al., 2000). The bacterial cultures used in the production of soy yogurt should be able to use sugars, such as sucrose, raffinose, and stachyose, so that the ideal acidity is obtained (MITAL; STEINKRAUS, 1979; WANG, MARINHO, CARVALHO, 1994). The metabolism of the carbohydrates, amino acids, and peptides from soybeans stimulates microbial growth, promoting sensory characteristics similar to those of traditional yogurt (BREN, SANTOS, ALMEIDA, 2010). Additionally, soy yogurt has some advantages over the conventional milk-based yoghurts, such as having lower saturated fat and lactose levels and the absence of cholesterol (TRINDADE et al., 2001).

The combination of the functional properties of the water-soluble soybean extract (WSSE) and LAB in low-level lactose or lactosefree products is an interesting approach, as it provides an important nutritional option for lactoseintolerant individuals. Thus, this study aimed to produce and characterize a fermented beverage made from WSSE and low-lactose semi-skimmed milk, with addition of strawberry pulp.

\section{MATERIAL AND METHODS}

\section{Fermentation process}

To obtain the fermented beverage, the dairy culture YO-MIX 300 LYO (Danisco ${ }^{\circledR}$, Cotia - SP) containing Streptococcus salivarius subsp. thermophilus and Lactobacillus delbrueckii subsp. bulgaricus was used. The freeze-dried culture was activated in semi-skimmed milk with a low level of lactose (Batavo Sensy, Teutônia - RS) by heating to $42^{\circ} \mathrm{C}$, and then inoculated with $5 \%(\mathrm{w} / \mathrm{v})$ lyophilised culture and incubated for $6 \mathrm{~h}$ at $42^{\circ} \mathrm{C}$.

The beverage base consisted of $62 \%$ WSSE (Purity, Maringá - PR) and 33\% semi-skimmed milk with a low level of lactose (Batavo Sensy, Teutonia - RS). The mixture was autoclaved at $105^{\circ} \mathrm{C}$ for 15 min to eliminate possible contaminants. The product was formulated as shown in Figure 1, and the fermentation was monitored for its titratable acidity up to $1.5 \%$ lactic acid (BRAZIL, 2000). In the meantime, a fruit syrup consisting of strawberries in natura and 22\% (w/v) sugar (Alto Alegre, Presidente Prudente - SP) was heated to obtain a jelly (GAVA, SILVA, FRIAS, 2009). Then, 0.1\% (v/v) of strawberry flavour (Mix, São Bernardo do Campo - SP) and $0.07 \%(\mathrm{v} / \mathrm{v})$ of red food colouring (Arco-Íris, São Paulo - SP) were added to the processed jelly, and the mixture was added to the fermented beverage at the end of the fermentation process.

\section{Physicochemical and microbiological evaluation of the product}

The fermentation was monitored through measurements of the $\mathrm{pH}$ (TEC-2 digital $\mathrm{pH}$ meter, Tecnal, Piracicaba - SP) and titratable acidity, using $10-\mathrm{mL}$ samples at 3-h intervals, up to $\mathrm{pH}$ 4.6. The acidity (\% lactic acid) was determined by titration with $0.1 \mathrm{M} \mathrm{NaOH}$, using phenolphthalein as an indicator (INSTITUTO ADOLFO LUTZ, 2008). Lactic acid bacterial counts were performed in the same time interval, using De Man-Rogosa-Sharpe agar (Himedia, Mumbai, India) for the enumeration of L. bulgaricus and lactose M17 agar (Himedia, Mumbai India) for $S$. thermophilus, with incubation at $42^{\circ} \mathrm{C}$ and $37^{\circ} \mathrm{C}$, respectively (SILVA, JUNQUEIRA, SILVEIRA, 2001).

The consumption-ready beverage was characterized for its protein content by the Kjeldahl method, for its fat content by Soxhlet extraction, for its ash content by incineration in a muffle furnace, and for its dry extract and total carbohydrate contents according to the methods described by INSTITUTO ADOLFO LUTZ (2008). Microbiological assays to detect faecal and thermotolerant coliforms and total count of moulds and yeasts were carried out as established by the Brazilian legislation (BRAZIL, 2001). 


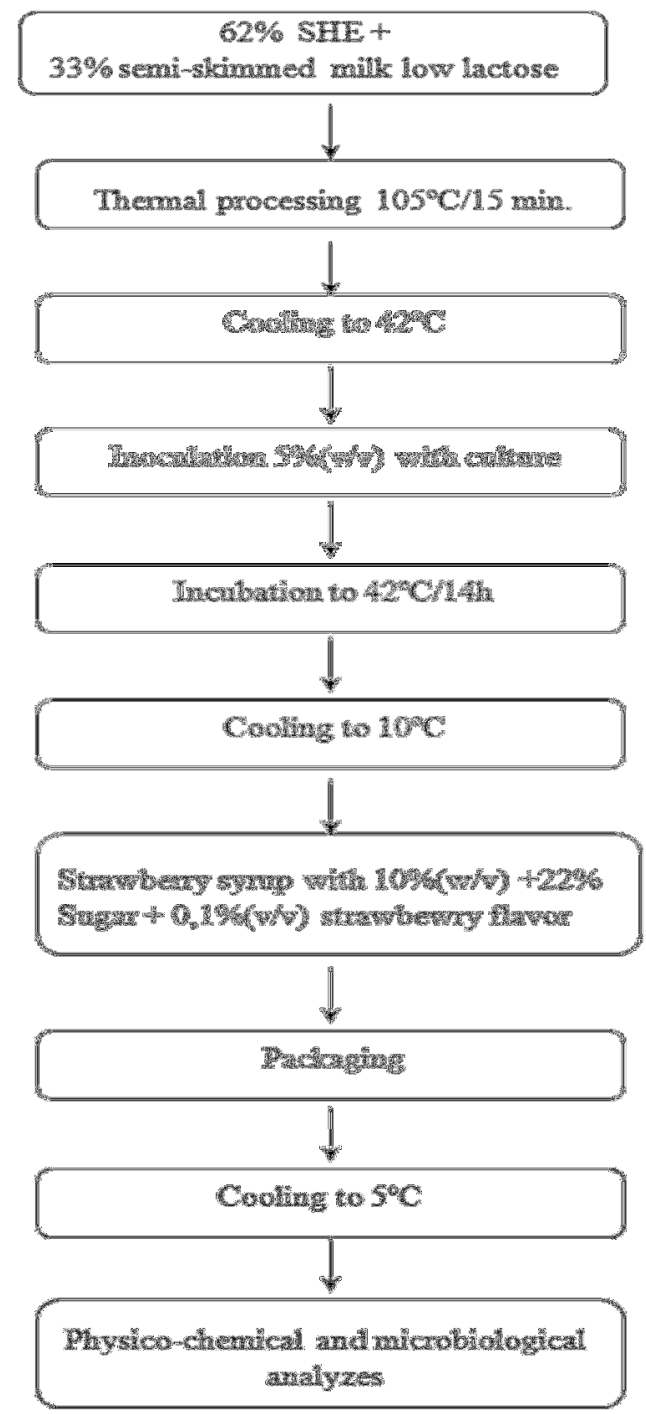

Figure 1. Production of the fermented beverage containing water-soluble soybean extract and low-lactose semi-skimmed milk.

\section{Sensory Evaluation}

Untrained panelists $(\mathrm{n}=60)$, made up of adults between 18 and 50 years of age, evaluated the product. The tests were performed in individual booths at the Laboratory of Sensory Analysis of UNOPAR (Piza, Londrina) under white light. Samples were coded with three digits in disposable $50-\mathrm{mL}$ cups in which $40 \mathrm{~mL}$ of the fermented beverage at a temperature of approximately $6-10^{\circ} \mathrm{C}$ was served. Acceptance of the attributes (viz. appearance, aroma, flavour, texture, and overall impression) was based on a structured 9-point hedonic scale, with the extremes anchored by 1 (dislike extremely) and 9 (like very much). In addition, the purchase intent was informed, with the scale ranging from 1 (decidedly I would buy) to 5 (decidedly I would not buy).

\section{Statistical Analysis}

The data were evaluated by analysis of variance and Tukey's multiple comparison of means at a 5\% significance level $(\mathrm{p}<0.05)$, using Statistica version 6.0 software (STATSOFT, 2001).

\section{RESULTS AND DISCUSSION}

The mixture containing low--lactose semiskimmed milk and WSSE presented an initial $\mathrm{pH}$ of 6.7. Throughout the 14-h fermentation period, the $\mathrm{pH}$ values decreased and the beverage showed typical characteristics of a fermented product, with a final $\mathrm{pH}$ of 4.5 and acidity of $0.8 \%$ lactic acid in the consumption-ready product (Figure 2). The acidity complied with Brazilian legislation and Mercosul criteria for fermented milk-based beverages, which 
stipulate that the acid value should range between $0.6 \%$ and $1.5 \%$ (BRAZIL, 2000; BRAZIL, 2007).

According to FUCHS et al. (2005), the typical $\mathrm{pH}$ and acidity characteristics of fermented milk are ideal parameters for gel formation due to protein coagulation. Other authors have reported similar data for yogurts produced with mixtures of cow's milk and soy products (CAMARGO et al., 2000; FIORENTINI et al., 2011; FUCHS et al., 2005). Although the present fermented beverage cannot be characterized as a yogurt since it does not present sufficient milk proteins for such designation (BRAZIL, 2000; BRAZIL, 2007), the usual designation for WSSE-based products is commonly 'soy yogurt' or 'soy milk beverage' (BREN, SANTOS, ALMEIDA, 2010; FIORENTINI et al., 2011; MANZANO et al., 2008; MORAES et al., 2006). The $\mathrm{pH}$ values observed in this study conferred product safety, since the most common pathogens in foods are inhibited at $\mathrm{pH}$ values below 4.5 owing to the presence of organic acids, which is characteristic of the metabolism of LAB.

The use of the traditional yogurt culture in the fermentation process is a good parameter for comparative purposes of this product with traditional fermented milks, since fermented WSSEbased beverages are marketed as an alternative to fermented milks. Moreover, controlling the acidity and $\mathrm{pH}$ is an important step in the fermentation process, because acidity may slow the hydration of the proteins, with subsequent phase separation due to gel contraction (THAMER; PENNA, 2006). Excessive acidity can also result in undesirable changes in sensory characteristics and reduce the culture viability (SOUZA et al., 2013; THAMER; PENNA, 2005; VINDEROLA, BAILO, REINHEIMER, 2000).

Regarding the development of the lactic acid culture as a function of $\mathrm{pH}$ and acidity (Figure $2)$, at time zero $(0 \mathrm{~h})$ of fermentation, the $\mathrm{LAB}$ counts in the substrate were $6.5 \times 10^{3} \mathrm{CFU} / \mathrm{ml}$ for $L$. bulgaricus and $2.9 \times 10^{6} \mathrm{CFU} / \mathrm{mL}$ for $S$. thermophilus. The peak of bacterial growth at time 6 $\mathrm{h}$ indicated a higher production of lactic acid and a sharp decrease in the $\mathrm{pH}$ of the medium. At the end of the fermentation process, the LAB counts had increased, as expected. After $14 \mathrm{~h}$ of fermentation, the final product had $8.5 \times 10^{3} \mathrm{CFU} / \mathrm{mL}$ of $L$. bulgaricus and $7.4 \times 10^{7} \mathrm{CFU} / \mathrm{mL}$ of $S$. thermophilus (Figure 2). According to Brazilian legislation (BRAZIL, 2000; BRAZIL, 2007), the minimum LAB count in yogurt should be $1 \times 10^{7}$ $\mathrm{CFU} / \mathrm{mL}$, and thus the fermented soy product of the present study was within the parameters required by law.

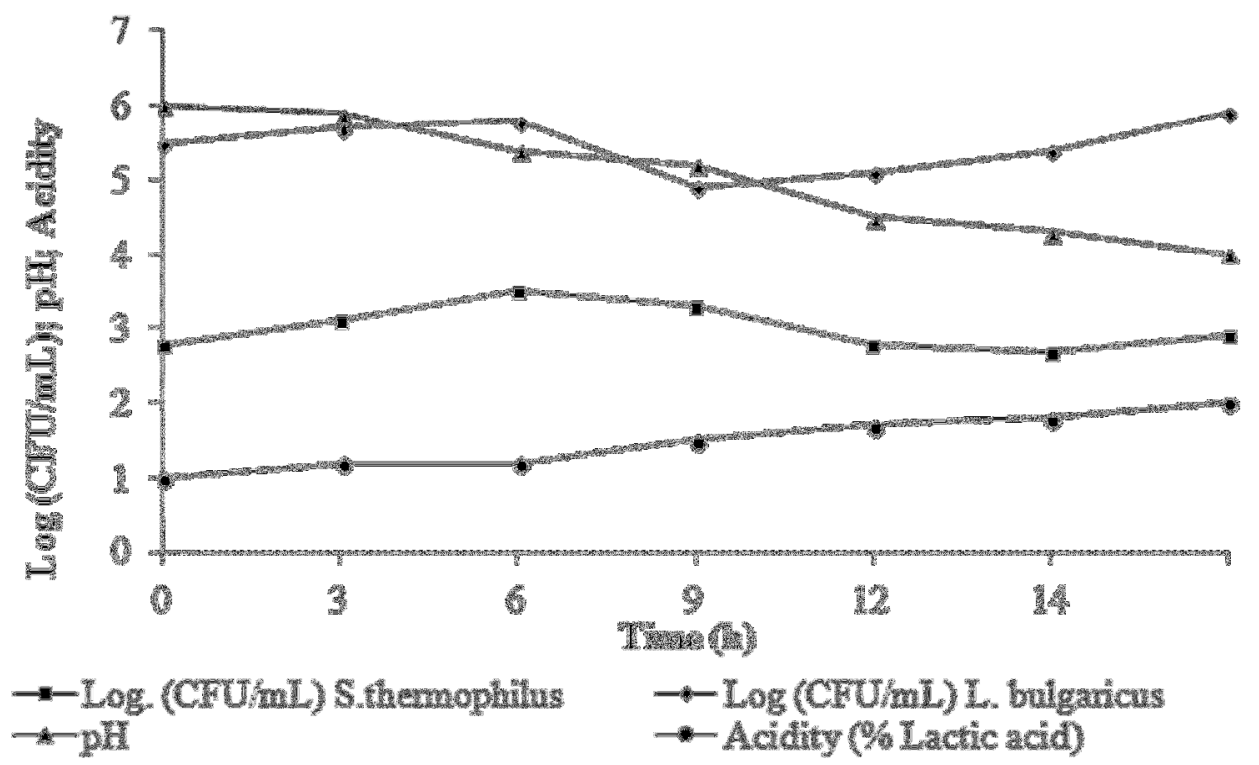

Figure 2. Relationship between the growth of Lactobacillus bulgaricus and Streptococcus thermophilus and the $\mathrm{pH}$ and titratable acidity during $14 \mathrm{~h}$ of fermentation and in the final product.

During fermentation, $S$. thermophilus and $L$. bulgaricus grow in symbiosis; that is, they have a dependency relationship in which $L$. bulgaricus grows best at the beginning of the fermentation, hydrolysing proteins with consequent release of amino acids, especially valine. This favours the multiplication of $S$. thermophilus, which in turn produces lactic acid and formic acid, reducing the $\mathrm{pH}$ of the medium for the optimal growth of $L$. bulgaricus (COURTIN; RUL, 2004; THAMER; PENNA, 2005). From the industrial point of view, a fermentation time of $14 \mathrm{~h}$ (Figure 2) can be 
considered long, since the fermentation of dairy products generally lasts from 3.5 to $6 \mathrm{~h}$ (DAVE; SHAH, 1997; THAMER; PENNA, 2006). Other authors have reported similar fermentation times for WSSE-based beverages supplemented with fermentable sugars (PINTHONG, MACRAE, ROTHWELL, 1980; SAITHO et al., 2014). Additionally, the proportion of milk used in the production process can affect the bacterial metabolism, increasing the fermentation time as a result of the lower availability of lactose as compared with traditional fermented dairy products. Lee, Moor, and Seo (1990) reported that LAB have a better ability to produce lactic acid on substrates with lactose levels similar to that of milk. However, WSSE is a suitable environment for LAB growth

Table 1. Chemical composition (\%) of the final product.

\begin{tabular}{lc}
\hline Parameter & Value $(\%)$ \\
\hline Acidity & $0.80 \% \pm 0.02$ \\
pH & $4.5 \pm 0.00$ \\
Carbohydrates & $14.92 \% \pm 0.18$ \\
Ash & $0.96 \% \pm 0.06$ \\
Lipids & $0.75 \% \pm 0.03$ \\
Total solids & $22.75 \% \pm 0.25$ \\
Protein & $2.19 \% \pm 0.08$ \\
\hline
\end{tabular}

owing to the presence of carbohydrates such as stachyose (OMOGBAI, IKENEBOMEH, OJEABURU, 2005).

With regard to the characteristics of the consumption-ready beverage, the results showed a final acidity of $0.80 \pm 0.02 \%$ lactic acid and $\mathrm{pH}$ value of $4.5 \pm 0.00$. The carbohydrate, total solids, and ash contents (Table 1) were similar to the values found by Fuchs et al. (2005) in a fermented WSSEbased beverage containing fibre. The protein and fat contents were $2.19 \pm 0.08 \%$ and $0.75 \pm 0.03 \%$, respectively, which corroborate the findings of Rodrigues and Moretti (2008) who studied a WSSEbased beverage containing peach pulp.

Values presented as means \pm standard deviation from the 3 independent production $(n=9)$

Negative results were obtained for the coliform, yeast, and mould counts. Therefore, the product was considered suitable for human consumption according to current Brazilian law related to the microbiological safety of foods (BRAZIL, 2001).

Regarding the sensory evaluation, the acceptance test showed mean scores of $>6.0$ on a $1-$ 9 scale for all attributes evaluated (Table 2), indicating a good acceptance of the product. In addition, the fermentation process can improve not only the sensory aspects but also the nutritional value of the final product, resulting in the development of suitable flavours and aromas (CAMARGO et al., 2000; FIORENTINI et al., 2011; MORAES et al., 2006). Moreover, the process also improves the bioactive compounds and decreases the anti-nutritional factors, which may contribute to the increased acceptance and positive effects of fermented soybean products (BREN, SANTOS, ALMEIDA, 2010; VAGADIA, et al.; 2018; WATANABE et al., 2017).

Table 2. Results of sensory analysis of the final product.

\begin{tabular}{lc}
\hline Attributes & Mean scores \\
\hline Appearance & $6.4 \pm 1.79$ \\
Aroma & $7.1 \pm 1.63$ \\
Flavour & $7.2 \pm 1.72$ \\
Texture & $7.0 \pm 1.63$ \\
Overall Impression & $6.8 \pm 1.70$ \\
\hline
\end{tabular}

Means scores from the 9 point hedonic scale, ranging from: 1-dislike extremely; 2- dislike very much; 3- dislike moderately; 4- dislike slightly; 5-neither like nor dislike; 6- like slightly; 7- like moderately; 8 - like very much; 9-like extremely.

The fermented beverage showed good purchase intent from most sensory panelists, resulting in scores of $\geq 4$ on a $1-5$ scale. This indicated that the majority of the consumers $(61 \%)$ 
had a positive impression of the product. Typically, although the WSSE has a clear colouration, this colour tends to darken after heat treatment. Despite the use of the food colouring and strawberry pulp, the product showed a dark pink colour which led the panelists to perceive it to be a guava colour and flavour rather than the expected strawberry. This may have influenced both the sensory evaluation and purchase intent. Although soy-based products have low consumers' acceptance due to the presence of off-flavour compounds, such as lipoxygenase (MORAES et al., 2006), the fermentation process and addition of the fruit pulp, sugar, and flavouring had made the final product pleasant according to the panelists.

\section{CONCLUSIONS}

The formulation with $62 \%$ WSSE and $33 \%$ semi-skimmed milk with low-level lactose was suitable for $\mathrm{LAB}$ fermentation. The $\mathrm{pH}$ value, acidity, and microbial growth resulted in a product with characteristics similar to those of traditional fermented milks. Therefore, compared to these products, the WSSE-based fermented beverage is in accordance with the current legislation, and its physicochemical and microbiological contents render it ready for consumption.

The sensory evaluation indicated that the product was well accepted by the consumers. Thus, it can be an alternative to the inclusion of soy products in food, in addition to meeting the needs of individuals with lactase deficiency and those on macrobiotic and vegetarian diets.

\section{ACKNOWLEDGMENT}

The authors thank the CAPES Coordenação de Aperfeiçoamento de Pessoal de Nível Superior and to the FUNADESP - Fundação Nacional de Desenvolvimento de Ensino Superior Particular for the financial support.

RESUMO: Alimentos funcionais são aqueles que, além da nutrição básica, promovem benefícios à saúde. Este trabalho teve como objetivo produzir uma bebida fermentada a partir de extrato hidrosolúvel de soja (EHS) e leite semidesnatado com baixa lactose. A bebida foi preparada utilizando uma mistura (v/v) contendo $62 \%$ de EHS, $33 \%$ de leite semidesnatado com baixa lactose e 5\% de inóculo contendo Lactobacillus delbrueckii subsp. Bulgaricus e Streptococcus salivarius subsp. Thermophilus. A fermentação foi acompanhada durante 14 horas, através das contagens das bactérias ácido lácticas, pH e a acidez titulável (\% de ácido láctico). A bebida fermentada pronta para consumo foi adicionada de uma calda de morango e caracterizada por sua composição centesimal, bem como por avaliação sensorial para os atributos: aparência, aroma, sabor, impressão global e intenção de compra. Além disso, a contagem das bactérias lácticas e presença de patógenos no produto foi avaliada. Após 14 horas de fermentação, o produto final refrigerado apresentou contagens de $8,5 \times 10^{3} \mathrm{UFC} / \mathrm{mL}$ e $7,4 \times 10^{7} \mathrm{UFC} / \mathrm{mL}$ para as bactérias L. bulgaricus e $S$. thermophilus respectivamente. O produto apresentou $14,93 \%$ de carboidratos, $0,76 \%$ de gordura, $0,96 \%$ de cinzas, $22,76 \%$ de sólidos totais e $2,19 \%$ de proteína. O produto não apresentou quaisquer patógenos, portanto, foi adequado aos padrões determinados pela legislação brasileira quanto à segurança microbiólogica. Com relação à avaliação sensorial, os provadores atribuíram em média nota 7,0 para todos os parâmetros avaliados, indicando que "gostaram moderadamente" da bebida. Ademais $61 \%$ dos avaliadores apontaram que "certamente ou provavelmente comprariam" o produto se estivesse disponível no mercado.

PALAVRAS-CHAVE: Streptococcus thermophilus. Lactobacillus bulgaricus. Soja. Bebida com baixa lactose.

\section{REFERENCES}

ANGELIS, R. C. Alimentos de origem vegetal são saudáveis: verdades e alguns questionamentos. Nutrição em Pauta, n. 57, p. 30-34, 2002.

BRAZIL. Ministério da Agricultura e do Abastecimento. Secretaria de Defesa Agropecuária. (2000). Departamento de Inspeção de Produtos de Origem Animal. Resolução No 05, de 13 de Novembro de 2000. Regulamento Técnico de Identidade e Qualidade de Leites Fermentados. Diário Oficial [da] União, Brasília, Seção 1, p. 9-12, 27 nov. 2000. 
BRAZIL. Ministério da Agricultura e do Abastecimento. Secretaria de Defesa Agropecuária. (2007). Departamento de Inspeção de Produtos de Origem Animal. Instrução Normativa No 46. Regulamento Técnico de Identidade e Qualidade de Leites Fermentados. Diário Oficial [da] União, Brasília, Seção 1, p. 5, 24. out. 2007.

BRAZIL. Ministério da Saúde. Agência Nacional de Vigilância Sanitária. (2016). Resolução RDC no 278, de 22 de setembro de 2005, atualizada em Julho de 2016. Alimentos com alegações de propriedades funcionais e ou de saúde, novos alimentos/ingredientes, substâncias bioativas e probióticos. Available at:< http://portal.anvisa.gov.br/alimentos/alegacoes >. Last accessed: 10 Aug 2018.

BRAZIL. Resolução RDC $n^{\circ}$. 12. (2001). Regulamento técnico sobre padrões microbiológicos para alimentos. Diário Oficial da União, Brasília, DF, 2001, Available at : < http://portal.anvisa.gov.br/documents/33880/2568070/RDC_12_2001.pdf/15ffddf6-3767-4527-bfac740a0400829b>. Last accessed: 10 Aug 2018.

BREN, E.; SANTOS, L.; ALMEIDA, J. V. P. Development of probiotic beverage from soybean milk. Revista Brasileira de Tecnologia Agroindustrial. Ponta Grossa, v. 1, n. 4, p. 100-108, 2010.

CAMARGO, D. S.; ALVEZ, G.; GARCIA, S.; MIZUBUTI, I. Y. Bebida fermentada à base de soro de leite e isolado proteico de soja. Semina: Ciências Agrárias. Londrina, v. 1, n. 21, p. 45-51, 2000.

COURTIN, P.; RUL, F. Interactions between microorganisms in a simple ecosystem: yogurt bacteria as a study model. Le Lait, Les Ulis. n. 84, p. 125-134, 2004.

DAVE, R. I.; SHAH, N. P. Viability of yoghurt and probiotic bacteria in yoghurts made from commercial starter cultures. International Dairy Journal, Barking, v. 1, n. 7, p. 31-41, 1997.

https://doi.org/10.1016/S0958-6946(96)00046-5

FIORENTINI, A. N.; BALLUS, C. A.; OLIVEIRA, M. L.; CUNHA, M. F.; KLAJN, V. M. The influence of different combinations of probiotic bacteria and fermentation temperatures on the microbiological and physicochemical characteristics of fermented lactic beverages containing soybean hydrosoluble extract during refrigerated storage. Food Science and Technology. Campinas, v. 3, n. 31, p. 597-607, 2011.

https://doi.org/10.1590/S0101-20612011000300008

FUCHS, R. H. B.; BORSATO, D.; BONA, E.; HAULY, M. C. O. Soy yogurt supplemented with oligofructose and inulin. Food Science and Technology. Campinas, v. 1, n. 25, p. 175-181, 2005.

https://doi.org/10.1590/S0101-20612005000100029

GAVA, A. J.; SILVA, C. A. B.; FRIAS, J. R. G. Tecnologia de Alimentos: Princípios e Aplicações. Ed. Nobel, São Paulo, Brazil. 2009, 511 pages.

HUANG, G.; CAI, W.; XU, B. Improvement in beta-carotene, vitamin B2, GABA, free amino acids and isoflavones in yellow and black soybeans upon germination. LWT - Food Science and Technology. 75: 488496, 2017. https://doi.org/10.1016/j.lwt.2016.09.029

INSTITUTO ADOLFO LUTZ (2008). Manual de Normas Analíticas do Instituto Adolfo Lutz. -in: Instituto Adolfo Lutz: Métodos físico-químicos para análise de alimentos (Ministério da Saúde), Brasília. pp. 823 881.

KEMPKA, A. P.; KRUGER, R. L.; VALDUGA, E.; DI LUCCIO, M.; TREICHEL, H.; CASIAN, R.; OLIVEIRA, D. Formulation of a peach-flavored dairy drink using alternative substrates and probiotic culture. Food Science and Technology. Campinas, v. 0, n. 28, p. 170-177, 2008. https://doi.org/10.1590/S010120612008000500027

LEE, S. Y.; MOOR, C. V.; SEO, A. Comparison of milk-based and soymilk-based yogurt. Journal of Food Science. Chicago, v. 2, n. 55, p. 532-536, 1990. https://doi.org/10.1111/j.1365-2621.1990.tb06803.x 
MANZANO, G. P. P.; DAIUTO, E. R.; JANZANTTI, N. S.; ROSSI, E. A. Aspectos sensoriais e físicoquímicos de "iogurtes" de soja com espessantes/estabilizantes a base de fécula de inhame (Dioscoreaalata), amido modificado e gelatina. CEPPA Bulletin. Curitiba, v. 2, n. 26, p. 287-296, 2008.

MARTIROSYAN, D. M. and SINGH, J. A new definition of functional food by FFC: what makes a new definition unique? Functional Foods in Health and Disease, v. 5, n. 6 p. 209-223, 2015.

MARTINS, C. A. O.; SEDIYAMA, C. S.; MOREIRA, M. A.; REIS, M. S.; ROCHA, V. S.; OLIVEIRA, M. G. S. Effect of genetic elimination of seed lipoxygenases on agronomic characteristics of soybean. Pesquisa Agropecuária Brasileira, Brasília, v. 20, n. 37, p. 1389-1398, 2002.

MITAL, B. K.; STEINKRAUS, K. H. Fermentation of soy milk by lactic acid bacteria; a review. Journal of Food Protection, v. 11, n. 42, p. 895-899, 1979. https://doi.org/10.4315/0362-028X-42.11.895

MORAES, R. M.; HAJ-ISA, N. M. A.; ALMEIDA, T. C. A.; MORETTI, R. H. Effects of deodorization on sensory characteristics of hydro soluble soybean extracts obtained from different technological processes. Food Science and Technology, Campinas, v. 1, n. 26, p. 46-51, 2006. https://doi.org/10.1590/S010120612006000100008

OMOGBAI, B. A.; IKENEBOMEH, M. J.; OJEABURU, S. I. Microbial utilization of stachyose in soymilk yogurt production. African Journal of Biotechnology, Nairobi, v. 9, n. 4, p. 905-908, 2005.

PENHA, L. A. O.; FONSECA, I. C. B.; MANDARINO, J. M.; BENASSI, V. T. A soja como alimento: valor nutricional, benéfico para a saúde e cultivo orgânico. CEPPA Bulletin, Curitiba, v. 1, n. 25, p. 91-102, 2007.

PINTHONG, R.; MACRAE, R.; ROTHWELL, J. The development of a soya-based yoghurt: I. Acid production by lactic acid bacteria. International Journal Food Science and Technology, Oxford, v. 6, n. 15, p. 647-652, 1980. https://doi.org/10.1111/j.1365-2621.1980.tb00985.x

RODRIGUES, R. S.; MORETTI, R. H. Caracterização físico-química de bebida proteica elaborada com extrato de soja e polpa de pêssego. CEPPA Bulletin. Curitiba, v. 1, n. 26, p. 101-110, 2008.

https://doi.org/10.5380/cep.v26i1.11797

SAITO, V. S.; DOS SANTOS, T. F.; VINDEROLA, C. G.; ROMANO ,C, NICOLI, J. R.; ARAÚJO, L. S. COSTA, M. M. ANDRIOLI, J. L.; UETANABARO, A. P. Viability and resistance of Lactobacilli isolated from cocoa fermentation to simulated gastrointestinal digestive steps in soy yogurt. Journal Food Science. Medford, v. 79, n. 2, p. 208-13. 2014. https://doi.org/10.1111/1750-3841.12326

SHAH, N. P. Functional cultures and health benefits. International Dairy Journal. Barking, v. 11, n. 17, p. 1262-1277, 2007. https://doi.org/10.1016/j.idairyj.2007.01.014

SILVA, M. S.; NAVES, M. M. V.; OLIVEIRA, R. B.; LEITE, O. S. M. Chemical composition and protein value of soybean residue compared to soybean. Food Science and Technology, Campinas, v. 3, n. 26, p. 571576, 2006. https://doi.org/10.1590/S0101-20612006000300014

SILVA, N.; JUNQUEIRA, V. C. A.; SILVEIRA, N. F. A. Manual de Métodos de Análise Microbiológica de Alimentos, Varela, São Paulo, Brazil, 2001, 229 pages.

SOUZA, A. H. P.; COSTA, G. N.; MIGLIORANZA, L. H. S.; MAIA-FURLANETO, L.; OLIVEIRA, A. F. Microbiological, physical, chemical and sensory characteristics of milk fermented with Lactobacillus plantarum. Acta Scientiarum - Health Science, Maringá, v. 1, n. 35, p. 125-131, 2013.

STATSOFT. Statistica for Window - Computer programa manual. 6.0 Tulsa: Statsoft Inc., 2001. 
THAMER, K. G.; PENNA, A. L. B. Characterization of functional dairy beverages fermented by probiotics and with the addition of prebiotics. Food Science and Technology, Campinas, v. 3, n. 26, p. 589-5959, 2006. https://doi.org/10.1590/S0101-20612006000300017

THAMER, K. G.; PENNA, A. L. B. Effect of whey, suggar and frutooligosacharides on the probiotic lactic acid bacteria population in fermented beverages. Revista Brasileira de Ciência Farmacêutica, v. 3, n. 41, p. 393-400, 2005.

TRINDADE, C. S.; TERZI, S. C.; TRUGO, L. C.; DELLA MODESTA, R. C.; COURI, S. Development and sensory evaluation of soy milk based yoghurt. Archivos Latinoamericanos de Nutrición, Caracas, v. 1, n. 51, p. 100-104, 2001.

UNITED STATES. Department of Health and Human Services. Food and Drug Administration. Food labeling: health claims; soy protein and coronary heart disease. Final rule. Federal Register, 64 (206): 5770 0-57733, October 26, 1999: [Rules and Regulations]. Available at: < https://www.fda.gov/downloads/aboutfda/reportsmanualsforms/reports/economicanalyses/ucm582748.pdf $>$. Last accessed: 10 Aug 2018.

VAGADIA, B. H.; VANGA, S. K.; SINGH, A.; GARIEPY, Y. AND RAGHAVAN, V. Comparison of conventional and microwave treatment on soymilk for inactivation of trypsin inhibitors and in vitro protein digestibility. Foods, Basel, v. 7, n. 1, p. 6, 2018. https://doi.org/10.3390/foods7010006

VINDEROLA, C. G.; BAILO, N.; REINHEIMER, J. A. Survival of probiotic in Argentina yogurts during refrigerate storage. Food Research International, Essex, v. 2, n. 33, p. 97-102, 2000.

https://doi.org/10.1016/S0963-9969(00)00011-9

WALKER, W. A.; GOULET, O.; MORELLI, L.; ANTOINE, J. M. Progress in science of probiotics: from cellular microbiology and applied immunology to clinical nutrition. European Journal of Nutrition, Darmstadt, v. 1, n. 45, p. 1-18, 2006. https://doi.org/10.1007/s00394-006-1101-1

WANG, S. H.; MARINHO, C. S.; CARVALHO, E. P. Preparation of soymilk yoghurt with different associations of lactic acid bacteria. Pesquisa Agropecuária Brasileira, Brasília, v. 10, n. 29, p. 1593-1601, 1994.

WATANABE, D.; ADÁNYI, N.; TAKÁCS, K.; MACZÓ, A.; NAGY, A.; GELENCSÉR, É.; PACHNER, M.; LAUTER, K.; BAUMGARTNER, S.; VOLLMANN, J. Development of soybeans with low P34 allergen protein concentration for reduced allergenicity of soy foods. Journal of the Science Food Agriculture, London, v. 97, n. 3, p. 1010-1017, 2017. 